\title{
A RECENT RECORD OF THE VOLCANO RABBITT (ROMEROLAGUS DIAZI) FROM THE NEVADO DE TOLUCA, STATE OF MEXICO.
}

\author{
GERARDO CEBALLOS ${ }^{1}$, BENJAMIN VIEYRA ${ }^{2}$ \\ AND JOSÉ RAMÍREZ PULIDO² \\ ${ }^{1}$ Instituto de Ecología, Universidad Nacional Autónoma de México, \\ Apartado Postal 70-275, 04510 México D. F., MEXICO \\ ${ }^{2}$ Departamento de Biología, Apostal Postal 55-535, Universidad Autónoma \\ Metropolitana - Iztapalapa, Mexico D.F. 09340
}

The volcano rabbit or zacatuche (Romerolagus diazi) represents the single species of a genus endemic to the Trans-volcanic belt in Central Mexico (Ceballos and Rodríguez, 1993; Ramírez Pulido and Müdespacher, 1987). This unique species of rabbit is distributed in high altitude grasslands and pine forests of the Sierra Nevada, Sierra Chichinautzin, and Sierra del Ajusco, which denote the eastern and southern limits of the Basin of Mexico. Due to the proximity to Mexico City, one of the three largest cities on earth, the volcano rabbit's habitat has been severely fragmented, and the species is considered critically endangered with extinction (Ceballos and Navarro, 1991). Habitat fragmentation has been caused by the spread of urbanized areas, agriculture, illegal forestry, and fires (Velázquez et al., 1996). Additionally, volcano rabbits are decreasing because they are regularly hunted as a food supply by local inhabitants and preyed upon by feral dogs (Cervantes et al., 1990). Presently, the geographic range of the volcano rabbit is estimated to be an area of approximately $381 \mathrm{~km}^{2}$ (Vázquez et al., 1996), one of the most restricted of all Mexican mammals (Ceballos et al., 1998).

Recently, we discovered a healthy population of volcano rabbits $4 \mathrm{~km}$ SO of Raíces (19 8' 27 " N and 100 38' 8" W), Nevado de Toluca, state of Mexico. The population is found in the northern slope of the volcano, close to the dirt road leading to the volcano's crater, in an area covered with open pine forest (Pinus spp) with abundant bunch grasses (Festuca tolucensis, Calamagrostis sp, Muhlenbergia sp) in the understory. We detected volcano rabbits along habitat adjacent to the road, approximately $2 \mathrm{~km}$ before and $6 \mathrm{~km}$ after the first alpine refuge, in an area of approximately 1,200 ha. However, based on interviews with local people we believe that the distribution of Volcano rabbits in the Nevado de Toluca covers a much larger region. Previous to our report Ticul Alvarez collected a specimen in the vicinity of the same area of our report (4 km S, 2 km W Raíces, 3350 m). However, recent surveys had failed to reveal the presence of the species in the Nevado de Toluca, so Velázquez et al. (1996) considered the species extirpated in that region. 
There are very important implications of our discovery for the conservation of the species. First, it current distribution is larger than recently estimated. For a species with such a restricted geographic range, finding new populations in additional geographic regions reduces the risk to extinction due to anthropogenic or stochastic events. Second, the region where the species was found in the Nevado de Toluca although impacted by human activities probably faces less immediate conservation problems than areas in close proximity to Mexico city like the Sierra del Ajusco or facing the direct or indirect effects of a catastrophic eruption of the Popocatepetl volcano. Finally, the discovery of this population enhances the importance of the Nevado de Toluca for the maintenance of the mammalian diversity of Mexico, leading to new insights for the conservation of that volcano.

\section{LITERATURE CITED}

Ceballos, G. and D. Navarro. 1991. Diversity and conservation of Mexican mammals. Pp. 167-198, in Latin American Mammalogy: History, Bidiversity, and Conservation (M. A. Mares and D. J. Schmidly, Eds). University of Oklahoma Press, Norman.

Ceballos, G. and P. Rodríguez. 1993. Diversidad y conservación de los mamíferos de México: II. Patrones de endemicidad. Pp. 87-198, in Avances en el estudio de los mamíferos de México (Medellín, R. y G. Ceballos, Eds.). Publicaciones Especiales No. 1, Asociación Mexicana de Mastozoología A.C., México D.F.

Cervantes, F., C. Lorenzo, and R. S. Hoffmann. 1990. Romerolagus diazi. Mammalian Species, 360:1-7.

Ceballos, G., P. Rodríguez, and R. Medellín. 1998. Assessing conservation priorities in megadiverse Mexico: mammalian diversity, endemicity, and endangerment. Ecological Applications 8:8-17.

Ramírez Pulido, J. and C. Mudespacher. 1987. Estado actual y perspectivas del conocimiento de los mamíferos de México. Ciencia 38: 49-67.

Velázquez, A., F. R. Paniagua and J. López-Paniagua (eds). Ecología y conservación del conejo zacatuche y su hábitat. Fondo de Cultura Económica, México D.F. 